\title{
Influence of suckling and continuous cow-calf association on the resumption of post-partum ovarian function in Bos indicus cows monitored by plasma progesterone profiles
}

\author{
E Mukasa-Mugerwa *, A Tegegne, R Franceschini \\ Animal Reproduction and Health Section, International Livestock Centre for Africa (ILCA), \\ PO Box 5689, Addis Ababa, Ethiopia
}

(Received 29 June 1989; accepted 21 January 1991)

\begin{abstract}
Summary - The effect of suckling on post-partum ovarian function was monitored by weekly plasma progesterone determinations using enzyme immunoassay in 16 Small East African Zebu (Bos indicus) cows maintained with a fertile bull. Five cows continuously suckled their calves (COS), but starting $30 \mathrm{~d}$ after calving 6 cows remained with their calves which were prevented from suckling using nose plates (NOS) while 5 calves were separated and penned (PEN). The mean ( \pm SE) interval from calving to first behavioural oestrus was $81 \pm 11 \mathrm{~d}$ and was significantly $(P<0.001)$ shorter for PEN (43 \pm 10 d) than NOS $(72 \pm 9$ d) or COS cows $(133 \pm 11$ d). COS cows nonetheless weaned heavier $(P<0.001)$ calves at 5 months. Ovarian activity determined by plasma progesterone levels $\geq$ $1.3 \mathrm{ng} / \mathrm{ml}$ indicated that "silent ovulation" was initiated in $44 \%$ of cows by $40 \pm 6 \mathrm{~d}$ post-partum. The results indicate that continuous suckling or constant cow-calf interaction extend the post-partum anoestrous interval in Ethiopian Zebu cows. However, early-weaned calves or those on restricted suckling would need extra nutritional supplementation to ensure continued growth.
\end{abstract}

\section{Zebu cow / post-partum anoestrus / suckling / progesterone}

Résumé - Influence de l'allaitement et de la présence permanente du veau avec sa mère sur la reprise des fonctions ovariennes post-partum chez les vaches Zébu (Bos indlcus). L'effet de l'allaitement sur les fonctions ovariennes post-partum a été suivi par le dosage (ELISA) hebdomadaire des niveaux de progestérone sanguine chez 16 vaches Zébu Small African accompagnées d'un taureau. Cinq vaches pouvaient allaiter leurs petits en permanence pendant toute la durée des observations (lot COS). Dans 2 autres lots, à partir de $30 j$ après le vélage, 6 vaches restaient avec leur veau mais ceux-ci étaient empêchés de téter par une plaque nasale (lot "NOS") et les veaux de 5 autres vaches étaient séparés de leur mère (lot «PEN"). L'intervalle moyen vélage/premier oestrus a été de $81 \pm 11 j(m \pm S E M)$ pour l'ensemble des vaches. Il était significativement plus court $(P<0,001)$ pour les vaches du lot PEN $(43 \pm 10 j)$ que pour celles des lots NOS $(72 \pm 9 j)$ et COS $(133 \pm 11 j)$. Les vaches "COS" ont sevré des veaux plus lourds $(\mathrm{P}<0,001)$ à 5 mois. L'activité ovarienne (indiquée par des niveaux de progestérone plasmatique $>1,3 \mathrm{ng} / \mathrm{ml}$ ) commence par une "ovulation silencieuse" chez $44 \%$ des vaches, $40 \pm 6 j$ après le vélage. Ces résultats montrent que

\footnotetext{
" Correspondence and reprints
} 
l'allaitement permanent ou la présence permanente des veaux près de leur mère augmente la durée de l'anoestrus post-partum chez les vaches Zébu. Cependant, les veaux soumis à un sevrage précoce ou à un allaitement restreint ont besoin d'un complément alimentaire pour poursuivre une croissance normale.

vache Zébu / anoestrus / post-partum / allaitement / progestérone

\section{INTRODUCTION}

Calving intervals in Bos indicus (Zebu) cows frequently exceed the desirable 365 d (Oyedipe et al, 1982; Mukasa-Mugerwa et al, 1989a). After parturition cows experience behavioural anoestrus of variable length depending on age, milk yield, nutrition, body weight and condition, health, season, uterine pathology, suckling and milking intensity (Oyedipe et al, 1982; Peters, 1984; Hanzen, 1986; Bluntzer et al, 1989). In the tropical regions where most Zebu cattle are found, farmers commonly share cow milk with the calf. Milk let-down in Zebu cows occurs only in the presence of their calves. Consequently, Zebu calves often suckle for 8-9 months before weaning.

The endocrinology of the post-partum period in Zebu cattle is not well known and the aim of this study was to: i) assess the effect of cow-calf association and continuous suckling on the resumption of oestral activity; and ii) monitor the temporal patterns of plasma progesterone during the post-partum period in grazing Zebu cows under uncontrolled mating.

\section{MATERIALS AND METHODS}

This study involved 16 multiparous Ethiopian Small East African Zebu cows with normal calving between March and September 1989 at the ILCA Debre Berhan research station, $120 \mathrm{~km}$ north of Addis Ababa at an altitude of $\approx 2850$ $\mathrm{m}$. Cows averaged $242 \pm 8 \mathrm{~kg}$ and ranged from
$5-7$ in body condition at calving ( 1 = emaciated; $9=$ obese). Station climatic data have been described previously (Mattoni et al, 1989). Cows grazed natural pastures during the day and were penned overnight and fed $2 \mathrm{~kg}^{-1}$ per head natural grass hay. Pastures were predominantly composed of Andropogon, Festuca and Pennisetum grass species mixed with Trifolium semense legume. Animals were watered daily and mineral licks were available ad libitum.

Cows were assigned at calving to 1 of 3 suckling treatments starting $30 \mathrm{~d}$ post-partum. Five cows continuously suckled their calves (COS). Suckling was prevented in 11 either by the application of calf nose-plates (NOS, $n=6$ ) of calf separation and penning (PEN, $n=5$ ). Penned calves were provided with grass hay ad libitum. NOS and PEN cows were hand-milked twice a day, morning and afternoon, in the presence of their calves. Cow milk yield was recorded prior to feeding the milk to the calf. Cow oestral activity was monitored by a fertile bull fitted with a Chinball marker and maintained permanently with the herd. Cow and calf body weights were recorded montly and all calves were weaned at 5 months.

Cows were bled weekly starting the last week of gestation until confirmed pregnant by rectal palpation $45 \mathrm{~d}$ post-mating. Blood samples were centrifuged immediately and plasma stored frozen at $-20^{\circ} \mathrm{C}$ until assayed for progesterone. Progesterone determination was carried out by the enzyme linked immunosorbent assay (ELISA) method using Ovucheck kits from Cambridge Veterinary Sciences. Procedural details of the technique were as per manufacturer's recommendations and have been described by Mukasa-Mugerwa et al (1989b). The intra- and inter-assay coefficients of variation for plasma containing $8 \mathrm{ng} / \mathrm{ml}$ were 0.18 and 0.27 , respectively. Data on cow post-partum anoestrous interval were analysed by least-squares procedures (SAS, 1987) to assess the effect of treatment and calving season. 


\section{RESULTS}

Mean cow body weights at calving and calf birth weight were similar for the 3 suckling groups (table I). No subsequent significant variation was observed in cow body weight, but there was a strong treatment effect on calf pre-weaning growth performance. COS calves exhibited faster average daily gains and were almost 2 to 3 times as heavy at weaning compared to their PEN and NOS counterparts $(P<$ 0.001).

The overall mean interval from calving to first behavioural oestrus, ie the postpartum anoestrous interval, was $81 \pm 11 \mathrm{~d}$ with a wide range from 31 to $192 \mathrm{~d}$. Anoestrous interval differed significantly $(P<$ 0.001 ) between groups, being almost 2 and 3 times longer in COS than NOS or PEN cows. Anoestrous intervals of $<100 \mathrm{~d}$ were recorded only for NOS and PEN cows (table 1). Further, there was no significant effect of cow weight change on postpartum anoestrous duration.

Plasma progesterone profiles are shown to illustrate 2 major phases of the calving to conception interval. The first was the calving to first oestrous interval with no measurable ovarian activity. The second was the first oestrus to conception interval (service period) characterized by normal and/or abnormal progesterone patterns such as the delaying effect of continuous suckling and constant cow-calf association, and initial silent ovulation or undetected oestrus (fig 1), false or unovulatory oestrus with no concomitant increase in progesterone level (fig 2), and repeat breeding, silent or undetected oestrus and return to oestrus after possible embryonic mortality (fig 3 ).

Mean plasma progesterone concentration prior to first behavioural oestrus was $0.56 \pm 0.35$ (SD) $\mathrm{ng} / \mathrm{ml}$. By considering cows to have resumed ovarian cyclicity based on progesterone levels $>1.3 \mathrm{ng} / \mathrm{ml}$ (the mean basal level plus 2 standard deviations), it was found that $7(44 \%)$ animals manifested initial "silent ovulation" (no oestrus detected) followed by a luteal phase which was shorter than the normal duration and plasma progesterone profiles lower than during the normal cycle, by $40 \mathrm{~d}$ after calving. Otherwise, after regular ova-

Table I. Effect of suckling regime on cow and calf body weight and post-partum anestrous interval in Zebu cows $(\mathrm{m} \pm \mathrm{SEM}$ ).

\begin{tabular}{|c|c|c|c|c|c|}
\hline \multirow{2}{*}{$\begin{array}{l}\text { Suckling } \\
\text { regime }\end{array}$} & \multirow[t]{2}{*}{ Obs } & \multicolumn{3}{|c|}{ Body weight $(\mathrm{kg})$} & \multirow{2}{*}{$\begin{array}{l}\text { Anoestrus } \\
\text { length } \\
\text { (d) }\end{array}$} \\
\hline & & At calving & 3 months & 5 months & \\
\hline PEN cows & 5 & $240 \pm 16$ & $251 \pm 35$ & $264 \pm 35$ & $43 \pm 10^{a}$ \\
\hline NOS cows & 6 & $243 \pm 15$ & $233 \pm 33$ & $232 \pm 34$ & $72 \pm 9^{b}$ \\
\hline cos cows & 5 & $254 \pm 16$ & $243 \pm 35$ & $236 \pm 35$ & $133 \pm 11 \mathrm{c}$ \\
\hline PEN calves & 5 & $17.5 \pm 0.8$ & $33.7 \pm 5.6^{\mathrm{a}}$ & $47.6 \pm 6.4^{\mathrm{a}}$ & \\
\hline NOS calves & 6 & $16.4 \pm 0.8$ & $31.2 \pm 5.3^{a}$ & $35.1 \pm 6.0^{\mathrm{a}}$ & \\
\hline COS calves & 5 & $19.8 \pm 0.8$ & $53.8 \pm 5.6^{b}$ & $83.2 \pm 6.4^{b}$ & \\
\hline
\end{tabular}

COS : continuous suckling; NOS = nose-plated calf; PEN = penned calf. Means in the same column with different superscripts differ significantly; $P<0.05$. 


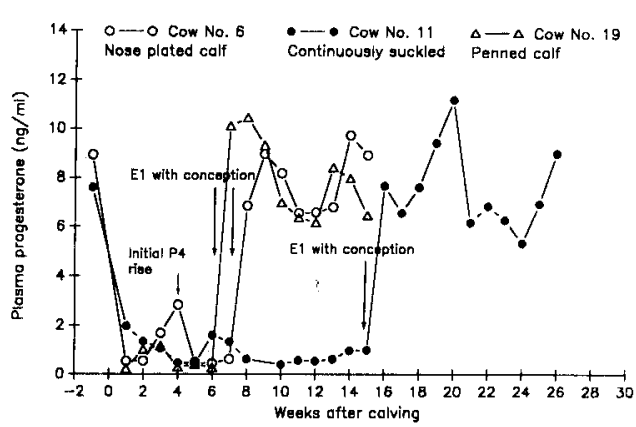

Fig 1. Progesterone profiles of Zebu cows showing the effect of suckling and cow-calf association on ovarian function. $\mathrm{E}$ : œstrus; P4 : progesterone.

rian cycles had resumed, $15 \%$ of heats were "silent" or undetected in $18 \%$ cows; and $6 \%$ of heats were false or unovulatory as they were not associated with subsequent increases in progesterone values. Extended luteal phases, suggestive of early embryonic mortality, were recorded in 2 cows.

Five $(31 \%)$ cows conceived at first mating, 2 on the second and the rest required more services. The shortest interval followed by conception at first mating was 31 d long.

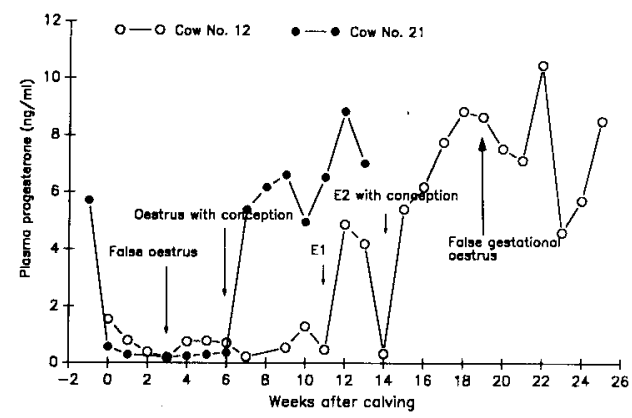

Fig 2. Progesterone profiles of Zebu cows showing "false" œstrus before and after conception.

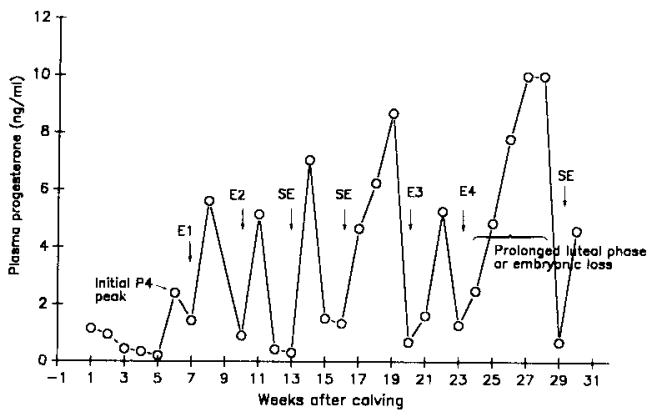

Fig 3. Progesterone profile of a Zebu cow showing repeat breeding $(E)$ and silent or undetected œstrus (SE).

\section{DISCUSSION}

The overall mean post-partum anoestrous interval of $81 \mathrm{~d}$ obtained in this study was within the range of 45-168 d previously reported for cattle in the tropics (Hansel and Alila, 1984) and 20-110 d for taurine cattle in temperate regions (Hanzen, 1986). The observation that our NOS and PEN cows conceived by $100 \mathrm{~d}$ indicates that Zebu cattle under restricted suckling are actually capable of short post-partum anoestrus periods and more frequent calving than COS cows. This is consistent with the results of Eduvie and Dawuda (1986) on suckled and non-suckled Nigerian Bunaji cows. Similar conception patterns have also been reported in Afrikaner cows (Wells et al, 1985) and taurine beef cattle (Wiltbank and Cook, 1958; Short et al, 1972).

The present lack of a significant effect of cow weight change on anoestrous duration, despite differences due to suckling manipulation, agrees with the observations of Short et al (1972) who found that if suckled and non-suckled cows had similar 
body weight losses, post-partum anoestrous interval was still longer in suckled cows. The longer anoestrous interval we observed for continuously suckled cows is in accord with the findings of Wiltbank and Cook (1958) and Short et al (1972).

Our results agreed with those of Holness et al (1980) who reported a shorter calving interval $(P<0.05)$ in Mashona and Afrikaner cows whose calves had been nose-plated for $8 \mathrm{~d} 50 \mathrm{~d}$ after calving than in continuously suckled cows. Further, the significant differences in post-partum anoestrous interval between PEN and NOS groups (43 vs 72 d) points to a delaying effect of cow-calf interaction on ovarian function. In mastectomised beef cows, ovulation and oestrus were suppressed for at least $50 \mathrm{~d}$ after calving by some cowcalf interaction independent of lactation or suckling (Viker et al, 1989). In contrast, Williams et al (1987) among others, concluded that the ability of suckling calves to suppress tonic LH secretion derives from cues not fully stimulated by the presence of non-suckled calves.

Our Zebu cows exhibited progesterone profiles similar to taurine cows, except for the extended post-partum anoestrus. Hormone levels were basal $(\leq 1.3 \mathrm{ng} / \mathrm{ml})$ before first behavioural oestrus. Prior to first oestrus, the frequency of $44 \%$ cows that showed an initial progesterone peak agreed with $50 \%$ observed in taurine cattle (Schams et al, 1978; Lamming et al, 1981) or their crosses (Ramirez-Iglesia et al, 1988) but was lower than shown in other reports (Rawlings et al, 1980; Webb et al, 1980). The frequency of these events might have been higher if progesterone concentration had been assayed more frequently than weekly.

These initial rises, probably resulting from luteinized follicles (Corah et al, 1974), may have an organising effect on the postpartum ovarian-pituitary-hypothalamic axis (Webb et al, 1977) and the reestablishment of regular oestrous cycles (Lamming et al, 1981; La Voie et al, 1981). But as our data indicate, these initial peaks are not exclusive prerequisites for conception. This is consistent with a previous report on taurine beef cows that conceived to natural service prior to any rise in milk progesterone levels (Peters and Riley, 1982).

Restricted suckling reduced the anoestrous interval but concurrently depressed calf growth rate, possibly because of less milk production. This would be unfavourable on commercial ranches where productivity and profitability is dependent on calf weight weaned per cow per year, and might be worse among traditional smallholders who often share cow milk with the calf. Furthermore, calf survival rate is also related to calf nutrition. Such milkrestricted calves would have to be fed extra nutritional supplement to realise the combined benefits of short anoestrous interval and continued calf growth. One way to reduce the cost of supplementation would be to adopt "once-daily" calf suckling from $30 \mathrm{~d}$, which Randel (1981) and Bluntzer et al (1989) found to have no effect on the weaning weight of Brahmancross heifers and cows.

In summary, the present results indicate that Ethiopian Zebu cows calving with average body weight and body condition can cycle and conceive by $100 \mathrm{~d}$ post-partum under natural mating conditions provided they are not continuously suckled. Therefore, improved cow management, especially as regards nutrition during the last trimester to ensure that cows calve with good weight and in good condition, minimal suckling and better oestrous detection, are required to ensure prompt post-partum ovarian cyclicity. 


\section{ACKNOWLEDGMENTS}

The authors thank $T$ Tibebu for proper animal management and G Abebe for excellent laboratory technical assistance.

\section{REFERENCES}

Bluntzer JS, Forrest DW, Harms PG, Beverly JR, Long CR (1989) Effect of suckling manipulation on post-partum reproduction in primiparous Brahman-cross cows. Theriogenology 32, 893-899

Corah LR, Quealy AP, Dunn TG, Kaltenbach CC (1974) Pre-partum and post-partum levels of progesterone and estradiol in beef heifers fed two levels of energy. $J$ Anim Sci 39, 380-385

Eduvie LO, Dawuda PM (1986) Effect of suckling on reproductive activities of Bunaji cows during the post-partum period. J Agric Sci (Camb) 107, 235-238

Hansel W, Alila HW (1984) Causes of postpartum anoestrus in cattle in the tropics. In: Nuclear Techniques in Tropical Animal Diseases and Nutritional Disorders. Proc Consult Meeting 13-16 June 1983, Vienna. Int Atomic Energy Agency, Vienna, 21-40

Hanzen C (1986) Endocrine regulation of postpartum ovarian activity in cattle: a review. Reprod Nutr Dev 26, 1219-1239

Holness DH, Hale DH, Hopley JDH (1980) Ovarian activity and conception during the postpartum period in Afrikaner and Mashona cows. Zimbabwe J Agric Res 18, 3-11

Lamming GE, Wathes DC, Peters AR (1981) Endocrine patterns of the post-partum cow. $J$ Reprod Fertil (suppl) 30, 155-170

La Voie V, Han DK, Foster DB, Moody EL (1981) Suckling effect on estrus and blood plasma progesterone in post-partum beef cows. J Anim Sci 52, 802-812

Mattoni M, Mukasa-Mugerwa E, Cecchini G, Sovani $S$ (1989) The reproductive performance of East African (Bos indicus) Zebu cattle in Ethiopia. I. Oestrous cycle length, duration, behavior and ovulation time. Theriogenology $30,961-971$
Mukasa-Mugerwa E, Bekele E, Taddese T (1989a) Type and productivity of indigenous cattle in central Ethiopia. Trop Anim Health Prod 21, 120

Mukasa-Mugerwa E, Azage T, Mattoni M, Cecchini G (1989b) Effect of oestrous synchronization with prostaglandin $F 2 \alpha$ in Ethiopian Highland Zebu (Bos indicus) cows. Anim Prod 48, 367-373

Oyedipe EO, Buvanendran V, Eduvie LO (1982) Some factors affecting the reproductive performance of White Fulani (Bunaji) cattle. Trop Agric (Trinidad) 59, 231-234

Peters AR (1984) Reproductive activity of the cows in the post-partum period. I. Factors affecting the length of the post-partum acyclic period. Br Vet J 140, 76-84

Peters AR, Riley GM (1982) Milk progesterone profiles and factors affecting post-partum ovarian activity in beef cows. Anim Prod 34, 145-153

Ramirez-Iglesia LN, Soto-Belloso E, GonzalezStagnaro C, Soto-Castillo G, Nucleo G (1988) Post-partum ovarian activity of crossbred primiparous cows in the tropics measured by skim milk progesterone. In: Proceedings 11 th Int Congress on Animal Reproduction \& Al Dublin, Ireland. Vol 4, 541 (abstr)

Randel RD (1981) Effect of once-daily suckling on post-partum interval and cow-calf performance of first calf Brahman $\times$ Hereford heifers. J Anim Sci 53, 755-757

Rawlings NC, Weir L, Todd J, Manns J, Hyland $\mathrm{JH}$ (1980) Some endocrine changes associated with the post-partum period of the suckling beef cow. J Reprod Fertil 60, 301-308

Statistical Analysis Systems (1987) SAS/STAT Guide for Personal Computers, Version 6 Edition, SAS Institute Inc, Cary, NC, 1028 pp

Schams D, Schallenberger E, Menzer C, Stangl J, Zottmeier K, Hoffmann B, Karg H (1978) Profiles of $\mathrm{LH}, \mathrm{FSH}$ and progesterone in post-partum dairy cows and their relationship to the commencement of cyclic functions. Theriogenology 10, 453-468

Short RE, Bellows RA, Moody EL, Howland BE (1972) Effects of suckling and mastectomy on bovine post-partum reproduction. J Anim Sci 34, 70-74 
Viker SD, McGuire WJ, Wright JM, Beeman KB, Kiracofe GH (1989) Cow-calf association delays post-partum ovulation in mastectomized cows. Theriogenology 32, 467-474

Webb R, Lamming GE, Haynes NB, Hafs HD, Manns JG (1977) Response of cyclic and post-partum suckled cows to injections of synthetic LH-RH. J Reprod Fertil 50, 203210

Webb R, Lamming GE, Haynes NB, Foxcroft GR (1980) Plasma progesterone and gonadotropin concentrations and ovarian activity in post-partum dairy cows. $J$ Reprod Fertil 59, 133-143
Wells PL, Holness DH, Freymark PJ, McCabe CT, Lishman AW (1985) Fertility in the Afrikaner cow. 2. Ovarian recovery and conception in suckled and non-suckled cows postpartum. Anim Reprod Sci 8, 315-326

Williams GL, Koziorowski M, Osborn RG, Kirsch JD, Slanger WD (1987) The post-weaning rise in tonic luteinizing hormone secretion in anoestrous cows is not prevented by chronic milking or the physical presence of the calf. Biol Reprod 36, 1079-1084

Wiltbank JN, Cook AC (1958) The comparative reproductive performance of nursed cows and milked cows. J Anim Sci 17, 640-648 